was covered by a thick coating of dust and sand, upon the surface of which were the usual white and yellowishgreen chloride crusts seen on such occasions, so rich in copper as to plate with that metal the iron nails of our boots. The crater had considerably enlarged, the edges were in an extremely unstable state, with often considerable strips marked off by cracks parallel to the free edge, so that, with a slight push by a stick, it was possible to detach large masses of the materials which form the sides of the crater in the recent cone of eruption. So dangerous were the edges, that it was but in two places that my experience indicated as being safe to approach and look over, and that even with several precautions; so that the fatal accident to Señor Silva Jardim, who lost his life here but a few hours after our departure, is not to be wondered at.

On looking down some 45 to $50 \mathrm{~m}$. beneath us, we could see the glow from a mouth some 2 or $3 \mathrm{~m}$. in diameter. The walls of the crater were concave, so that although overhanging at the top, yet a plumb-line let fall from the edge would strike the bottom of the cliff. The crater bottom was roughly plain, due to the combination of a talus all round, and an attempt at a cone encircling the main vent. It will be thus seen that the crater cavity was of the form of a convex-sided cylinder, or more simply barrel-shaped, with its upper diameter some 50 to $55 \mathrm{~m}$.

With much difficulty we made our way around to the north side of the cone of eruption, which had now lost its usual loose scoria surface, which was buried beneath a thick coat of sand and dust, covered with a thin saline crust on its surface. The upper limit of the radial rift, which we were prevented from examining three weeks previously, on account of its giving out so much vapour as to constitute the temporary escape aperture of the volcano, had now become quiescent, so that we could fully examine it. Only a current of hot air was now issuing from it, but I was able to collect some fine masses of crystallized molysite and kremersite from its edges. Its average breadth was about $0.50 \mathrm{~m}$., where it traversed old compict lava, but of course it disappeared as soon as it reached the looser materials. "The real azimuth of its orientation, which we could now determine with greater accuracy than when we were walking over hot rock and enveloped in hot irritating vapours, proves to be, as it radiates away from the axis of Vesuvius, about $15^{\circ}$ west of north. It curves then a little to the north, and near the foot of the great cone it again assumes nearly the same azimuth as at starting, an arrangement which is quite evident when the Vesuvian cone is regarded from the Punta del Nasone. From that, the highest point of Somma, the lower extremity of the rift lies a little to the right or west, and faces that part of the Somma ridge which corresponds to the upper extremity of the Vallone Cancherone.

In the forenoon of June 30 much dust had fallen at the lower railway station, of which we collected some bagsful. It is the usual fine sandy material of these eruptions, and consists of the pulverized materials of the cone of eruption.

Having passed the night at the lower railway station, the next day we crossed the Atrio, ascended to the western extremity of the ridge of Somma, and followed it along so as to get a general bird's-eye view of the whole scene of the eruption, and take photographs of the more important points. As one stands on the Punta del Nasone and embraces that magnificent view of Vesuvius and the Atrio del Cavallo, one sees at their feet the new lava-stream in the form of the letter the horizontal portion of which is still being prolonged down the Atrio towards the Fossa della Vetrana. In the middle of the ridge we found a thin coating of fine red dust which had reached thus far from the crater. Much of the Atrio was also covered by the same material. Scaling the cliff face just beyond the Cognulo di Ottajano to the Atrio del Cavallo, we again visited the lower point of the outburst. Most of the beautiful fumaroles were in a state of ruin, and lined by good-sized crystals of hæmatite and mixed chloride crusts. Here the lava was quite solid, though at one point was a hole, some $50 \mathrm{~m}$. from the base of the great cone, where we could see the molten rock flowing lazily along about a metre beneath our feet. The lava at the end of the flow was making considerable progress to the westwards, and stood opposite dyke I3.

Since then, few changes have taken place in the mountain : the crater still gets larger, dust is thrown out, and the lava descends. These phenomena are capable of continuing for months if the drainage opening does not enlarge.

As the eruption progresses, I will send you further details. H. J. JohNSTON-LAvis.

\section{THE PRODUCTION OF MUSICAL NOTES FROM NON-MUSICAL SANDS.}

THAT I have succeeded in producing musical notes from sand that was never before musical, and am also able to produce similar results from certain mute or "killed" musical sands which have been temporarily deprived of their musical properties, has already been announced in the Chemical Newes (vol. Ixiv. No. I6́50).

It is not necessary now to give the details of the numerous experiments which led up to this discovery; it will be, perhaps, sufficient for present purposes, to state that in November 1888 I published a paper $^{1}$ in which I propounded a theory to account for the cause of musical sounds issuing from certain sands. After giving various reasons for my conclusions, I said :- "It occurred to me, then, that the music from sand was simply the result of the rubbing together of the surfaces of millions of periectly clean grains of quartz, free from angularities, roughness, or adherent matter, in the form of clinging fragments investing the grains, and that these microlithic emissions of sound, though individually inaudible, might in combination produce a note sufficiently powerful to be sensible to us."

Having described numerous experiments, and drawn attention to the hopeful results obtained from the "millet. seed" sand, my paper concluded with the following:"From what 1 have now told you, I think we may conclude that music may be produced from sand if (I) the grains are rounded, polished, and free from fine fragments; (2) if they have a sufficient amount of 'play' to enable them to slide one against the other; $(3)$ if the grains are perfectly clean; and (4) if they possess a certain degree of uniformity in size, and are within a certain range of size."

On June 20 last I visited Studland Bay for the purpose of carrying out some new experiments. I found that the musical patch emitted tones louder and more pronounced than I had ever heard them there before. The best results were obtained by drawing a thick deal rod, on to the end of which I had fixed a resonator, over the surface of the sand; sounds produced in this way were beard unmistakably for a considerable distance. The patch averaged $7 \frac{1}{2}$ yards in width, and ran parallel with the trend of the shore for some hundreds of yards. The sand on the sea side of the patch was fine, and emitted notes of a high pitch; that on the land side was coarse, and emitted notes of a lower pitch. The rod drawn across the patch gave, therefore, a great variety of pitch. Many other interesting facts cannot now be referred to, but it is important to state that some of this sand, when taken off the patch, and struck in a box, gave out notes as it did in situ. On trying this sand subsequently at home, the coarse emitted distinct

\footnotetext{
I Read before the Bournemouth Society of Natural Science.
}

NO. I I 36 , VOL. 44$]$ 
notes of a low pitch, but the fine was mute. This was, so far as I know, the first time that the Studland sand had been musical off the patch.

According to my theory, if the number of grains with polished surfaces could be increased in this fine sand, the number of vibrations would increase also, and so intensify the note, and cause it to become audible; this could only be done, however, by introducing a certain percentage of grains fulfilling the required conditions. To obtain such grains and to introduce them gradually until the necessary number should have been added, would have been a tedious process; and it occurred to me then that the same result might be obtained if the sand were struck in a vessel with a hard and polished interior. I placed, therefore, this fine sand in a teacup, and on striking it, found that it emitted a high, shrill note ( $\mathrm{A}$ in altissimo), which was far more intense than that given when it formed a part of the patcb.

When polished grains of sand are in contact with the sides and bottom of a glazed porcelain vessel, it is obvious that there are numerous points of contact between two polished surfaces-the sand grains and the vessel-and that on striking the surface of the sand, the friction necessary to produce the vibrations of a musical note is induced between these points.

This I proved by placing the same sand in various vessels with rough interiors, and by lining these glazed or polished vessels with silk, \&c., but in no case would this sand emit notes unless the grains were in direct contact with the glazed or polished surfaces. This peculiarity is not in any way dependent upon the sonorous properties of the vessel used, for it may be "deadened" with impunity, and the note will remain unaltered.

The results of numerous experiments show that musical sand of the Eigg type-i.e. sand possessing in great perfection the physical conditions necessary for the production of music - will be musical in receptacles of whatever composition or form, though in some of these it emits notes "under protest" only."

Those sands which are of the Studland Bay type-i.e. having the necessary physical conditions less perfectly developed, and are usually mute except in situ-will emit music only in vessels possessing hard and glazed interiors, and, as a rule, of a certain form; while some of the more "sulky" types of sand not only need a vessel of hard and glazed interior, and definite form, but also require a box, or small pedestal of wood (which I call a "coaxer"), on which this vessel must stand before the notes emitted become audible. A "sulky" sand was rendered far more musical by being sifted, washed, and boiled, giving out, after this treatment, notes without the aid of the "coaxer." "

After discovering what could be done with such simple apparatus, it occurred to me to try, under similar conditions, some of my abandoned sands-those unmusical sands that had been, during a period of four or five years, treated unsuccessfully for music.

One sand (an iron-sand composed of more or less polished grains, quartz, and much dust formed of denser minerals) gave a very hopeful "swish" (explained in my paper of 1888) in a certain porcelain vessel, and from this - by (I) sifting in sieves, to eliminate the fine material, and to insure uniformity in size of grain ; (2) rolling down an inclined plane of frosted glass, to separate the rounded grains from the angular quartz; and (3) boiling in dilute hydrochloric acid, to cleanse the surfaces-I succeeded in producing a sand that, in certain glazed vessels, emits musical notes as clear as those emitted from any of my

"When musical sands sound "under protest" they give out high, shrill notes. The smallest quantity of musical sand from which I can obtain a true note is a thimbleful of the Eigg sand. Small quantitie; emit notes of a high pitch.

"Many musical sands are quickly " killed" by constant striking, because the harder minerals present abrade the softer as they rub together, and this forms a fine dust. musical sands but that of Eigg. This sand gives $F$ in altissimo, but it very soon becomes "killed" because of the fine dust and loss of polish that is the inevitable result of the attrition of the grains. There remains but one thing to be done, and that is to produce a sand which, like that of Eigg, will be musical in almost any receptacle, and I have reason now to think that this will not be very difficult.

It has not been possible here to record more than the merest outline of what has been done, or to give instances of the interesting capriciousness of these sands; it should be understood, however, that no ordinary beach or cliff sand has the slightest inclination to "sing" under any of the "coaxing" methods at present known to me.

Cecil Carus-Wilson.

\section{NOTES.}

Sir Michael Hicks-Beach, who previously gave a negative answer to the request made by the Executive Committee of the British Institute of Preventive Medicine, having reconsidered his decision, has now granted the required license to register the Institution as a Limited Liability Company, with the omission of the word "Limited." The license, however, is not to be construed as expressing approval by the President of the Board of Trade of experiments on animals, or in any way affecting the exercise by the Secretary of State of his discretionary powers to grant a vivisection license to the proposed Institute. The articles of association have been signed, and the Institute is now duly registered. The following gentlemen have already expressed their willingness to serve on the Council : Sir Joseph Lister, Chairman, Sir Charles A. Cameron, Mr. Watson Cheyne, Prof. Michael Foster, Prof. Greenfield, Prof. Victor Horsley, Sir William Roberts, Sir Henry Roscoe, Prof. Roy, Prof. Burdon-Sanderson, Dr. Pye-Smith. Dr. Armand Ruffer, of 19 Iddesleigh Mansions, Westminster, S.W., will act as honorary secretary until the first meeting of the Council.

THE graduation ceremony at the close of the summer session of the University of Edinburgh was held on Monday. Principal Sir William Muir, Vice-Chancellor, presided. Prof. Kirkpatrick presented for the honorary degree of Doctor of Laws Colonel Sir Colin Campbell Scott Moncrieff, K.C.M.G., C.S.I., R.E., remarking that, through his work as chief officer of the irrigation works of the Nile, it could be said that Sir Colin had created a greater and an infinitely freer, happier, and more prusperous Egypt than it was before. As a gallant officer, a distinguished man of science, a statesman of high merit, and, above all, as a benefactor of his fellow-creatures, Sir Colin was pre-eminently worthy of the highest of their academic honours. The honorary degree of Doctor of Law was then conferred in absentia on Prof. Simon Newcomb, Washington.

Sir Joseph FAyrer has been elected a Corresponding Member of the Royal Italian Society of Hygiene. Sir Joseph has also been promoted from the grade of Foreign Corresponding Member to that of Foreign Associate of the French Academy of Medicine.

Prof. DU BoIs-REYMond, the distinguished physiologist of Berlin, has been awarded the Gold Medal for Science.

MR. J. E. Keeler has been elected Professor of Astrophysics in the Western University of Pennsylvania, and Director of the Allegheny Observatory. Mr. F. W. Very is associated with him as Adjunct Professor of Astronomy. It is expected that the Observatory will continue its researches on important problems in the domain of astro-physics.

IT is stated that Siam, following the example of Japan, is commencing to Europeanize her institutions. The founding of

NO. I I 36, VOL. 44] 